\title{
Argümantasyona Dayalı Laboratuar Uygulamaları: Bilimsel Süreç Becerilerine ve Laboratuar Dersine Yönelik Tutuma Etkisi
}

\section{Argumentation Based Activities in the Laboratory: The Effect of on Science Process Skills and Attitudes towards Laboratory Course}

\author{
Safiye ASLAN*
}

- Geliş Tarihi: 05 Aralık 2014 • Kabul Tarihi: 22 Ocak 2016 • Yayın Tarihi: 31 Ekim 2016

\begin{abstract}
ÖZ: $\mathrm{Bu}$ çalışmada; argümantasyona dayalı laboratuar uygulamalarının öğretmen adaylarının bilimsel süreç becerilerine ve laboratuar dersine yönelik tutumlarına etkisi araştırılmıştır. Karma araştırma desenin kullanıldığı bu çalışmaya, Fen Bilgisi Öğretmenliği bölümünde okuyan 53 öğrenci katılmıştır. Bu öğrencilerden, Bilimsel Süreç Becerileri Testi'nden aldıkları ön test puanlarına göre; bilimsel süreç becerileri açısından düşük ve yüksek seviyeli iki grup oluşturulmuştur. Bu yolla; argümantasyona dayalı laboratuar uygulamalarının bilimsel süreç becerileri daha düşük ve daha yüksek düzeyde olan öğrencilerin bilimsel süreç becerilerine etkisinin kıyaslanması da hedeflenmiştir. Argümantasyona dayalı laboratuar uygulamaları, argüman odaklı sorgulama ve argümantasyon tabanlı bilim öğrenme yaklaşımı temel alınarak tasarlanmıştır. Çalışmada argümantasyona dayalı laboratuar uygulamalarının, öğrencilerin kimya laboratuarı dersine karşı tutumlarına etkisini belirlemek amacıyla Kimya Laboratuarı Dersi Tutum Ölçeği ve yapılan uygulamaya ilişkin öğrenci görüşlerini belirlemek için de yazılı görüşme formu kullanılmıştır. Araştırma sonucunda; argümantasyona dayalı laboratuar uygulamalarının öğrencilerin bilimsel süreç becerilerini geliştirdiği, bunun yanında bilimsel süreç becerileri daha düşük seviyedeki öğrencilerin bilimsel süreç becerilerini geliştirmede daha etkili olduğu bulunmuştur. Uygulamanın, her iki gruptaki öğrencilerin laboratuar dersine yönelik tutumlarının olumlu yönde artmasına neden olduğu görülmüştür. Uygulamaya ilișkin görüşleri alınan 19 öğrencinin büyük çoğunluğu, uygulamanın faydalı olduğuna ilişkin görüş bildirmiş ve uygulamanın hem akademik başarılarına hem de kişisel gelişimlerine katkı sağladığını belirtmiştir.
\end{abstract}

Anahtar sözcükler: Argümantasyon, laboratuar, bilimsel süreç becerileri, tutum

\begin{abstract}
In this study, the effect of argumentation based laboratory activities on science pre-teachers' science process skills and attitudes towards laboratory course was investigated. The study which was designed on mixed methods research was conducted with 53 science pre-teachers studying in Science Teaching Department. These students were grouped into two groups which consisted of students with high and low science process skills according to their pre-test scores from Science Process Skills Test (SPST). This way, it was aimed to compare the effect of argumentation based laboratory activities on students with lower and higher science process skills. Argumentation based laboratory activities were designed according to Argument-Driven Inquiry and Science Writing Heuristic approaches. SPST, Chemistry Laboratory Behaviour Scale, and written interview form were used to measure the effect of argumentation based laboratory activities on students' science process skills, attitudes towards chemistry laboratory course, and their views about the application, respectively. The study concluded that the argumentation based laboratory activities improved students' science process skills, as well as with a higher improvement for students with lower science process skills. It was seen that the application provided a positive increase in the students' attitudes towards laboratory courses in both groups. A high majority of the 19 students whose views were acquired stated that the application was beneficial and that it contributed to both their academic success and personal development.
\end{abstract}

Keywords: Argumentation, laboratory, science process skill, attitude

\section{GİRiș}

Son yirmi yılda dünyada fen eğitiminde yaşanan paradigma değişikliğii, Türkiye'de de kendini göstermiş ve 2005 yllından itibaren fen eğitiminde bu paradigmalara dayalı olarak reformlar yapılmaya başlanmıştır. 2005-2013 yılları arasında yapılandırmacı yaklaşımı temel alan reform çalışmaları, 2013 yılından itibaren araştırma ve sorgulamaya dayalı öğrenmeyi dahil

\footnotetext{
*Yrd. Doç. Dr., Aksaray Üniversitesi, Eğitim Fakültesi, Aksaray, e-posta: safiyeaslan@gmail.com
} 
ederek devam etmiştir (Talim Terbiye Kurulu Başkanlığı [TTKB], 2005, 2006, 2013). 2013 yılında yayımlanan fen bilimleri programında, argümantasyonu bünyesinde barındıran araştırma ve sorgulamaya dayalı fen öğrenimi ve öğretimi üzerinde durulmaktadır (TTKB, 2013). Fen eğitiminde argümantasyonun kullanımına ilişkin ilk vurgu, bu programda yer almaktadır. Fen eğitiminde yapılan bu reformların uygulanmasında öğretmenler anahtar role sahiptirler. Öğretmenlerin öğrencilerinin argümantasyonu kullanabilmelerini sağlamaları için öncelikle kendilerinin fen öğrenimi bağlamında argümantasyon deneyimi yaşamaları önemlidir. Ancak on y1l öncesinin öğretim programları, öğretmenlerin büyük çoğunluğunun öğrenim hayatları boyunca geleneksel yaklaşımların uygulandığ bir süreçten geçmiş olduklarını ve argümantasyona aşina olmadıklarını düşündürmektedir. Bu durum; fen eğitiminde yapılan reformlar ile uygulamalar arasındaki makasın açılmasına neden olabilir. Bu sorunun çözümüne yapılabilecek en önemli katkılardan biri, öğretmenlerin fen alanında yaşanan değişikleri tecrübe ettikleri bir öğrenme ortamında yetişmelerini sağlamak olacaktır. Bu çalışmada, öğretmen adaylarının laboratuar aktivitelerini yürütürken argümantasyon deneyimi yaşamalarını sağlayarak, gerçekleştirilen etkinliklerin öğretmen adaylarının bilimsel süreç becerilerine ve laboratuar dersine karşı tutumlarına etkisinin incelenmesi amaçlanmıştır.

\subsection{Argümantasyona Dayalı Laboratuar Uygulamaları}

Laboratuar uygulamalarının öğrenci merkezli olarak yürütülmesine ve yenilikçi uygulamaların kullanılmasına vurgu yapan pek çok çalışma bulunmaktadır (Acar ve Tarhan, 2013; Alkan ve Erdem, 2013; Aydın, 2011; Doymuş, Şimşek ve Karaçöp, 2007; Özmen, Demircioğlu, Burhan, Naseriazar ve Demircioğlu, 2012; Tüysüz, 2010). Bu çalışmalardan bir kısmı laboratuar uygulamaları sırasında argümantasyonu kullanmayı ele almıştır. Bu çalışmalarda argümantasyonun odak olduğu modeller, birbirleri ile benzerlik göstermekle birlikte içerdikleri birtakım farklılıklardan dolayı farklı adlarla ifade edilmiş ve uygulamalarının yürütülmesine ilişkin farklılıklar içeren çatılar sunulmuştur. Aşağıda literatürde konuya ilişkin olarak en çok karşılaşılan iki model ele alınmıştır.

\subsubsection{Argüman odaklı sorgulama (Argument-Driven Inquiry, ADI)}

Argüman odaklı sorgulama modeli, araştırma ve sorgulama ile argümantasyonun birleştirilmesi esasına dayanır. Model, bilimsel araştırma ve sorgulama süreci boyunca argümanın ve argümantasyonun rolü üzerine büyük bir vurgu yapmaktadır (Walker, Sampson, Grooms, Anderson ve Zimmerman, 2012; Walker ve Sampson, 2013). Model, özellikle lisans seviyesindeki öğrencilerin katıldığı laboratuar aktivitelerinin yürütülmesinde kullanılmak amacıyla geliştirilmiştir. Bu amaca ek olarak; bilimsel bilginin üretilmesinde ve onaylanmasında bilimsel argümantasyonun rol oynadığı vurgusuyla öğrencilere önemli zihin alışkanlıkları kazandırmak ve eleştirel düşünme becerilerinin geliştirilmesine yardımcı olmak için tasarlanmıştır (Walker ve diğerleri, 2012). Model; görev ve araştırma sorusu belirleme aşaması, metod geliştirme, veri toplama ve analiz etme aşaması, geçici bir argüman oluşturma aşaması, argümantasyon oturumu, araştırma raporu hazırlama, çift-gizli akran değerlendirmesi, araştırma raporunun gözden geçirilmesi olmak üzere yedi basamak içermektedir (Walker ve diğerleri, 2012; Walker ve Sampson, 2013). Bu basamaklar; öğrencilerin veri toplamak için yöntem geliştirmelerine, araştırmalarını uygulamalarına, araştırma sorularına yanıt bulabilmek için verileri kullanmalarına, yazma aktiviteleriyle uğraşmalarına ve tüm çalışmalarını başkalarının incelemesine açık bir şekilde gerçekleştirmelerine olanak sağlayacak niteliktedir (Walker, Sampson ve Zimmerman, 2011). 


\subsubsection{Argümantasyon tabanl bilim öğrenme (Science Writing Heuristic, SWH)}

Argümantasyon Tabanlı Bilim Öğrenme, laboratuar araştırma ve sorgulamaları ile bilimsel bilginin üretilmesine yardım eden ve bilim ile ilgili anlayış oluşturmak için öğrenmede yazmanın gücünden faydalanan bir model olarak ifade edilebilir. Öğrenme için yazma, modelin en önemli vurgularından biridir (Keys, Hand, Prain ve Collins, 1999). Bu açidan değerlendirildiğinde modelin, rehberli araştırma ve sorgulamaya dayalı öğrenme ile yazma stratejilerini birleştirdiği görülmektedir (Burke, Hand, Poock ve Greenbowe, 2005). Modelin geliştirilmesinde; yapılandırmacı yaklaşım, bilimsel okuryazarlık, bilimin doğasına ilişskin anlayışlar ve okul laboratuarlarında kullanılan yazma biçimleri ile ilgili tartışmalar dikkate alınmıştır (Keys ve diğerleri, 1999). Modelin öğretmen ve öğrenci şablonu olmak üzere iki bileşeni bulunmaktadır (Keys ve diğerleri, 1999; Günel, Kıngır ve Geban, 2012). Öğretmen şablonu; öğrencilerin laboratuar ortamında bilimsel araştırma ve sorgulama çalışmaları ile ilgilenirken, grup ve sınıf müzakeresi yapmaları için öğretmene rehberlik eder ve bir dizi öneri sunar. Öğrenci şablonu ise; yarı yapılandırılmış bir yazma formudur. Öğrencilere bilimsel araştırma ve sorgulama çalışmalarının anlamı ile ilgili müzakere yapma ve yazma aktiviteleriyle ilgilenme fırsatı sağlar, soru, iddia, soru-iddia ilişkisi, delil ve iddia-delil ilişkisi gibi konuların yer aldığı argüman yapısı hakkında anlayış geliştirmelerini destekler (Keys ve diğerleri, 1999; Nam, Choi ve Hand, 2011). Modelin bu iki bileşeni incelendiğinde, modeldeki yazma dişındaki en önemli diğer vurgunun müzakere fazı olduğu görülmektedir. Modelde müzakere fazı yalnızca sınırlı bir tartışma olarak görülmemekte, okuma ve yazma aracılığıyla fen kavramlarını yapılandırma süreci olarak değerlendirilmektedir (Keys ve diğerleri, 1999). Bu bağlamda müzakereler, öğrencilerin önbilgileri ile yeni bilgileri arasındaki uyuşmazlıkların çözümü temeline dayanır (Günel ve diğerleri, 2012).

\section{YÖNTEM}

\section{1. Çalışma Grubu}

Araştırmanın evrenini Türkiye'de bulunan bir devlet üniversitesinin eğitim fakültesinin fen bilgisi öğretmenliği bölümünde okuyan öğrenciler oluşturmuştur. Çalışma; amaçlı örnekleme yöntemiyle seçilen Genel Kimya Laboratuarı-II dersini alan 74 öğrenciden derse sürekli devam eden 53 fen bilgisi öğretmen adayı ile 2012-2013 eğitim öğretim yılının II. döneminde gerçekleştirilmiştir. Çalışmaya başlamadan önce öğrencilere veri toplama aracı olarak kullanılan Bilimsel Süreç Becerileri Testi (BSBT) ön test olarak uygulanmış ve öğrenciler bu testten aldıkları toplam puanlara göre sıralamaya tabi tutulmuşlardır. Testten daha düşük puan alan 26 öğrenci GRUP 1, daha yüksek puan alan 27 öğrenci GRUP 2 şeklinde ayrılmıştır. Böylece çalışmaya; bilimsel süreç becerileri düşük (GRUP 1) ve yüksek (GRUP 2) düzeyde olmak üzere iki grupla başlanmıştır. Her iki grupta da argümantasyona dayalı laboratuar etkinlikleri aynı şekilde yürütülmüştür.

\subsection{Veri Toplama Araçları}

\subsubsection{Bilimsel süreç becerileri testi (BSBT)}

Argümantasyona dayalı laboratuar etkinliklerinin, öğrencilerin bilimsel süreç becerilerine etkisini ölçmek amacıyla; Burns, Okey ve Wise (1985) tarafından geliştirilmiş ve 1992 yılında Geban, Özkan ve Aşkar (1992) tarafından Türkçeye çevrilen ve Cronbach alfa güvenirlik katsayısı 0,81 olarak bulunan Bilimsel Süreç Becerileri Testi (BSBT) kullanılmıştır. Bu test, lisans düzeyindeki öğrencilerin bilimsel süreç becerilerini ölçmek amacıyla kullanımı sıklıkla tercih edilen ve güvenilir bulunan bir ölçektir (Açışlı ve Turgut, 2011; Ateş ve Bahar, 2002; 
Bilen ve Aydoğdu, 2012; Kanlı, 2007; Kanlı ve Temiz, 2006; Temel ve Morgil, 2007). BSBT'nde değişkenleri tanımlama (12 soru), operasyonel tanımlama (6 soru), hipotez kurma (9 soru), veri ve grafik yorumlama (6 soru), araştırma tasarlama (3 soru) olmak üzere toplam 36 çoktan seçmeli soru yer almaktadır.

\subsubsection{Kimya laboratuarı dersi tutum ölçeği (KLDTÖ)}

Argümantasyona dayalı laboratuar etkinliklerinin, öğrencilerin kimya laboratuarı dersine karşı tutumlarına etkisini belirlemek amacıyla literatürden alınan, 22 olumlu 13 olumsuz madde içeren, Cronbach alfa güvenirlik katsayısı 0,93 olarak hesaplanan, Likert tipi beș dereceli tutum ölçeği kullanılmıştır (Kaya, 2012). KLDTÖ, uygulama öncesinde ve sonrasında öğrencilerin kimya laboratuarı dersine karşı tutumlarını belirlemek amacıyla her iki gruba da uygulanmıştır.

\subsubsection{Yazılı görüsşme formu}

Öğrencilerin argümantasyona dayalı laboratuar etkinlikleri ile ilgili görüşlerini belirlemek amacıyla; araştırmaya katılan her iki grubun öğrencilerinden BSBT son testinden düşük, orta ve yüksek puan alan üçer öğrenci olmak üzere toplam 19 öğrencinin uygulamaya ilişkin görüşleri alınmıştır. Görüşler; "Genel Kimya Laboratuarı-II dersinin argümantasyona dayalı uygulamalar ile yürütülmesini faydalı buldunuz mu? Uygulamaları faydalı bulduysanız, hangi açıdan/açılardan faydalı bulduğunuzu, faydalı bulmadıysanız neden faydalı bulmadığınızı açıklayınız." sorularına cevap verdikleri yazılı form yoluyla alınmıştır. Öğrencilerin yazılı formları öğrencilere okunmuş, anlaşılmayan yerler için öğrencilerden açılama istenmiş veya anlaşıldığı şekli öğrencilere ifade edilerek doğru anlaşılıp anlaşılmadığına ilişkin görüşleri alınmış, böylece öğrenci görüşlerine netlik kazandırılmaya çalışılmıştır. Öğrenci görüşleri içerik analizine tabi tutulmuştur. Bu amaçla elde edilen yazılı veriler, alanında uzman iki akademisyen tarafından incelenmiş ve ayrı ayrı kodlanmıştır. Yapılan kodlamaların güvenirliği için Miles ve Huberman'ın (1994) önerdiği; Güvenirlik = Görüş birliği / (Görüş birliği + Görüş ayrıllı̆̆1) X 100 formülü kullanılmıştır. Hesaplama sonucunda güvenirlik \%92 olarak bulunmuştur. Güvenirlik hesabının \%70'in üzerinde olması, veri analizi açısından güvenirliğin sağlandığını göstermektedir (Miles ve Huberman, 1994).

\subsection{Uygulama}

Çalışma süresince argümantasyona giriş aktivitesi ve kimyasal kinetik (derişimin, sıcaklığın ve katalizörün kimyasal tepkimenin hızına etkisi), kimyasal denge, asitler ve bazlar (asidik ve bazik özellik gösteren maddelerin tanınması ve asit-baz titrasyonu), gazlar, reaksiyon 1Sıs1, elektroliz konularını içeren dokuz laboratuar deneyi her iki grupla da gerçekleştirilmiştir. Çalışma kapsamında her iki grupta da Genel Kimya Laboratuarı-II dersi argümantasyona dayalı olarak aynı şekilde yürütülmüştür. Argümantasyona dayalı olarak yürütülen laboratuar uygulamaları yukarıda açıklanan argüman odaklı sorgulama ve argümantasyon tabanlı bilim öğrenme modelleri temel alınarak düzenlenmiştir. Bu çalışmadaki uygulamaya ilişkin çatı aşağıda sunulmuştur. Bu çatı, uygulamada takip edilen aşamaları göstermektedir.

\begin{tabular}{ll}
\hline & Argümantasyona Dayalı Laboratuar Uygulaması \\
\hline Laboratuara giriş & $\begin{array}{l}\text { 1. Konuyla ilgili öğrencilerin ön bilgilerinin ortaya çıkarılması. } \\
\text { 2. Başlangıç sorularının önce bireysel, ardından grup tartışması yapılarak oluşturulması ve } \\
\text { yazılması. }\end{array}$ \\
\hline Deneysel çalışma & 3. Grup üyeleri arasında iş bölümünün yapılması. \\
& 4. Deneye ilişkin beklentilerin önce bireysel, ardından grup tartışması ile belirlenmesi ve \\
& yazılması. (Ne bekliyorum?) \\
& 5. Deneysel prosedürün uygulanması (Prosedür hazır olarak verilmiştir). \\
6. Gözlemlerin kaydedilmesi. (Gözlemlerim)
\end{tabular}




\begin{tabular}{|c|c|}
\hline $\begin{array}{l}\text { Verilerin } \\
\text { değerlendirilmesi }\end{array}$ & $\begin{array}{l}\text { 7. Deneye ilişkin beklentiler ile gözlemlerin önce bireysel, ardından grup tartışması yapılarak } \\
\text { karşılaştırılması ve yazılması. (Ne bekliyorum?-Gözlemlerim) }\end{array}$ \\
\hline $\begin{array}{l}\text { İddia ve gerekçe } \\
\text { oluşturma }\end{array}$ & $\begin{array}{l}\text { 8. Deneye ilişkin değişkenleri ve değişkenler arasındaki ilişkiyi ifade ederek verilerin gözden } \\
\text { geçirilmesi ve yazılması (Grup tartışması). } \\
\text { 9. Verilere dayalı olarak iddia oluşurulması ve yazılması (Bireysel çalışma-grup tartışması). } \\
\text { 10. Veriler ile iddia arasındaki ilişkiyi açılayacak gerekçe oluşturulması ve yazılması } \\
\text { (Bireysel çalışma-grup tartışması). }\end{array}$ \\
\hline $\begin{array}{l}\text { Kendini } \\
\text { değerlendirme }\end{array}$ & $\begin{array}{l}\text { 11. Başlangıç düşünceleri ile gelinen noktadaki düşüncelerin karşılaştırılması ve yazılması. } \\
\text { Fikirlerim nasıl değişti? (Bireysel çalışma). }\end{array}$ \\
\hline $\begin{array}{l}\text { Grup-uzman } \\
\text { değerlendirmesi }\end{array}$ & 12. Öğrencilerin düşüncelerindeki değişmenin grup-uzman tartışması ile değerlendirilmesi. \\
\hline
\end{tabular}

\subsection{Verilerin Analizi}

Çalışmada BSBT’nde yer alan tüm becerilerin toplamından elde edilen veriler her iki grup için de normal dağılım gösterdiği için; bu verilerin analizinde parametrik istatistiklerden t-Testi kullanılmıştır. Bilimsel süreç becerilerinin alt boyutlarında ise her iki grup için de değişkenleri belirleme, operasyonel tanımlama, veri ve grafik yorumlama, araştırma tasarlama becerilerine ilişkin puanlar normal dağılım göstermemiş, hipotez kurma becerisine ilişkin puanlar GRUP 1 için normal dağılım gösterirken GRUP 2 için normal dağılım göstermemiştir. Normal dağılım göstermeyen verilerin analizinde nonparametrik istatistiklerden Wilcoxon İşaretli Sıralar Testi kullanılarak karşılaştırma yapılmıştır. Bunun için SPSS (Statistical Package for the Social Science) 20.0 programı kullanılmıştır.

\section{BULGULAR}

Bu bölümde; BSBT ve KLDTÖ puanları için yapılan analizlerin yer aldığı nicel bulgulara ve Yazılı Görüşme Formu'ndan elde edilen verilerinin analizine ilişkin nitel bulgulara yer verilmiştir.

\subsection{Nicel Bulgular}

Tablo 1: Uygulama öncesi BSBT ön testinin gruba göre betimsel analiz sonuçları

\begin{tabular}{cccc}
\hline Grup & $\mathrm{N}$ & $\overline{\mathrm{X}}$ & SD \\
\hline GRUP 1 & 26 & 18.96 & 2.23 \\
GRUP 2 & 27 & 25.40 & 3.16 \\
\hline
\end{tabular}

Tablo 1'deki veriler, GRUP 2'nin BSBT başarısının ( $\overline{\mathrm{X}}=25.40)$, GRUP 1'in BSBT başarısına ( $\bar{X}=18.96)$ göre daha fazla olduğunu göstermektedir. $\mathrm{Bu}$ fark, araştırmada argümantasyona dayalı laboratuar etkinliklerinin bilimsel süreç becerileri açısından daha düşük ve daha yüksek seviyedeki öğrencilerin olduğu gruplardaki etkisini test etme amacına uygundur.

Tablo 2'ye göre GRUP 2 öğrencilerinin bilimsel süreç becerilerinin tüm alt boyutlarının ön testinden aldıkları puanların ortalamasının, GRUP 1 öğrencilerinin aldıkları puanların ortalamasından daha yüksektir. Operasyonel tanımlama ve veri ve grafik yorumlama becerilerinde, gruplar arasındaki puan ortalamaları farkı düşük iken özellikle değişkenleri belirleme becerisine ait puanların ortalamaları arasındaki farkın yüksek olduğu dikkat çekmektedir. Çalışmaya başlarken bilimsel süreç becerilerinin alt boyutlarına da bakılmış, ancak grupları ayırmada kriter olarak toplam süreç becerileri dikkate alınmıştır. 
Tablo 2: Becerilere ilişkin ön test puanlarının gruba göre betimsel analiz sonuçları

\begin{tabular}{lllll}
\hline Bilimsel Süreç Becerileri & Grup & $\mathrm{N}$ & $\overline{\mathbf{X}}$ & SD \\
\hline Değişkenleri Belirleme & GRUP 1 & 26 & 5.03 & 1.90 \\
& GRUP 2 & 27 & 8.48 & 2.11 \\
\hline Operasyonel Tanımlama & GRUP 1 & 26 & 2.92 & 1.19 \\
& GRUP 2 & 27 & 3.14 & 1.06 \\
\hline \multirow{2}{*}{ Hipotez Kurma } & GRUP 1 & 26 & 4.96 & 1.34 \\
& GRUP 2 & 27 & 6.29 & 1.51 \\
\hline Veri ve Grafik Yorumlama & GRUP 1 & 26 & 4.30 & 1.08 \\
& GRUP 2 & 27 & 5.00 & .83 \\
\hline Araştırma Tasarlama & GRUP 1 & 26 & 1.73 & .66 \\
& GRUP 2 & 27 & 2.48 & .57 \\
\hline
\end{tabular}

Tablo 3'e göre GRUP 1 ve GRUP 2 öğrencilerinin argümantasyona dayalı laboratuar uygulamaları sonucunda bilimsel süreç becerilerinin istatistiksel olarak anlamlı bir şekilde geliştiği görülmektedir $(\mathrm{t}(25)=-11.55, \mathrm{p}<.05 ; \mathrm{t}(26)=-2.75, \mathrm{p}<.05)$. GRUP 1 öğrencilerin uygulama öncesi BSBT puanlarının ortalaması 18.96 iken uygulama sonrasında 25.84'e, GRUP 2 öğrencilerinin ise 25.40 iken 27.11'e yükselmiştir. $\mathrm{Bu}$ bulgu, argümantasyona dayalı laboratuar uygulamalarının bilimsel süreç becerileri açısından hem düşük hem de yüksek seviyeli öğrencilerin bilimsel süreç becerilerini geliştirdiğini göstermektedir.

Tablo 3: BSBT ön test ve son test ortalama puanlarının t-testi sonuçları

\begin{tabular}{clccccccc}
\hline Grup & Ölçüm & $\mathrm{N}$ & $\overline{\mathrm{X}}$ & $\mathrm{S}$ & $\mathrm{sd}$ & $\mathrm{t}$ & $\mathrm{p}$ \\
\hline GRUP 1 & Ön Test & 26 & 18.96 & 2.23 & 25 & -11.55 & .000 \\
& Son Test & 26 & 25.84 & 3.70 & & \\
\hline GRUP 2 & Ön Test & 27 & 25.40 & 3.16 & 26 & -2.75 & .010 \\
& Son Test & 27 & 27.11 & 3.54 & & & \\
\hline
\end{tabular}

Tablo 3, 4 ve 5 incelendiğinde; GRUP 1 öğrencilerinin bilimsel süreç becerilerine yönelik ön test-son test puanları, hem tüm alt boyutlar hem de toplam süreç becerileri açısından anlamlı düzeyde artış gösterdiği görülmektedir. $\mathrm{Bu}$ artış, argümantasyona dayalı laboratuar uygulamalarının GRUP 1 öğrencilerinin bilimsel süreç becerilerinin gelişimine neden olduğu anlamına gelmektedir. Bu sonuç, bilimsel süreç becerileri açısından zayıf öğrencilerin bilimsel süreç becerilerinin geliştirilmesinde, argümantasyona dayalı laboratuar uygulamalarının etkili olduğu şeklinde yorumlanabilir. Tablo 4, GRUP 2 öğrencileri açısından incelendiğinde; bilimsel süreç becerilerine yönelik ön test-son test puanları tüm alt boyutlar açısından anlamlı düzeyde artış göstermemiştir. Ancak toplam süreç becerileri açısından yapılan karşılaştırma (Tablo 3); son test puanlarının ön test puanlarına göre anlamlı bir şekilde arttığını göstermektedir $(\mathrm{t}(26)=$ $2.75, \mathrm{p}<.05)$. Bu bulgu; bilimsel süreç becerileri açısından yüksek seviyedeki öğrencilerin bu becerilerini, argümantasyona dayalı laboratuar uygulamalarının geliştirdiğine işaret etmektedir. 
Tablo 4: Becerilere göre ön test-son test puanlarına ilişkin Wilcoxon işaretli sıralar testi sonuçları

\begin{tabular}{|c|c|c|c|c|c|c|c|}
\hline $\begin{array}{l}\text { Bilimsel Süreç } \\
\text { Becerileri }\end{array}$ & Grup & Son test-Ön test & $\mathrm{n}$ & Sira Ort. & Sira Top. & $\mathrm{Z}$ & $\mathrm{p}$ \\
\hline \multirow{2}{*}{$\begin{array}{l}\text { Değişkenleri } \\
\text { Belirleme }\end{array}$} & 胥- & $\begin{array}{l}\text { Negatif sıra } \\
\text { Pozitif sıra } \\
\text { Eşit } \\
\end{array}$ & $\begin{array}{l}3 \\
21 \\
2 \\
\end{array}$ & $\begin{array}{l}3.00 \\
13.86 \\
- \\
\end{array}$ & $\begin{array}{l}9.00 \\
291.00 \\
-\quad \\
\end{array}$ & $4.04 *$ & .000 \\
\hline & $\sum_{\tilde{j}}^{2} N$ & $\begin{array}{l}\text { Negatif sıra } \\
\text { Pozitif sıra } \\
\text { Eşit } \\
\end{array}$ & $\begin{array}{l}8 \\
13 \\
6 \\
\end{array}$ & $\begin{array}{l}10.13 \\
11.54 \\
-\quad\end{array}$ & $\begin{array}{l}81.00 \\
150.00 \\
- \\
\end{array}$ & $1.21 *$ & .223 \\
\hline \multirow{2}{*}{$\begin{array}{l}\text { Operasyonel } \\
\text { Tanımlama }\end{array}$} & 胥- & $\begin{array}{l}\text { Negatif sıra } \\
\text { Pozitif sıra } \\
\text { Eşit }\end{array}$ & $\begin{array}{l}3 \\
17 \\
6 \\
\end{array}$ & $\begin{array}{l}9.33 \\
10.71 \\
-\quad \\
\end{array}$ & $\begin{array}{l}28.00 \\
182.00 \\
-\quad \\
\end{array}$ & $2.95 *$ & .003 \\
\hline & 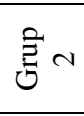 & $\begin{array}{l}\text { Negatif sıra } \\
\text { Pozitif sıra } \\
\text { Eşit }\end{array}$ & $\begin{array}{l}7 \\
15 \\
5 \\
\end{array}$ & $\begin{array}{l}9.86 \\
12.27 \\
-\end{array}$ & $\begin{array}{l}69.00 \\
184.00 \\
-\quad \\
\end{array}$ & $1.92 *$ & .055 \\
\hline Hipotez Kurma & $\sum_{0}^{2} N$ & $\begin{array}{l}\text { Negatif sıra } \\
\text { Pozitif sıra } \\
\text { Eşit }\end{array}$ & $\begin{array}{l}10 \\
13 \\
4 \\
\end{array}$ & $\begin{array}{l}9.80 \\
13.69 \\
-\quad \\
\end{array}$ & $\begin{array}{l}98.00 \\
178.00 \\
-\quad \\
\end{array}$ & $1.25 *$ & .221 \\
\hline \multirow{2}{*}{$\begin{array}{l}\text { Veri ve Grafik } \\
\text { Yorumlama }\end{array}$} & 胥- & $\begin{array}{l}\text { Negatif sıra } \\
\text { Pozitif sıra } \\
\text { Eşit }\end{array}$ & $\begin{array}{l}3 \\
14 \\
9 \\
\end{array}$ & $\begin{array}{l}8.67 \\
9.07 \\
-\quad \\
\end{array}$ & $\begin{array}{l}26.00 \\
127.00 \\
-\quad \\
\end{array}$ & $2.42 *$ & .015 \\
\hline & $\sum_{0}^{0} N$ & $\begin{array}{l}\text { Negatif sıra } \\
\text { Pozitif sıra } \\
\text { Eşit }\end{array}$ & $\begin{array}{l}7 \\
9 \\
11 \\
\end{array}$ & $\begin{array}{l}7.64 \\
9.17 \\
-\quad \\
\end{array}$ & $\begin{array}{l}53.50 \\
82.50 \\
-\quad \\
\end{array}$ & $.77 *$ & .439 \\
\hline \multirow{2}{*}{$\begin{array}{l}\text { Araştırma } \\
\text { Tasarlama }\end{array}$} & き- & $\begin{array}{l}\text { Negatif sıra } \\
\text { Pozitif sıra } \\
\text { Eşit }\end{array}$ & $\begin{array}{l}1 \\
12 \\
13\end{array}$ & $\begin{array}{l}5.00 \\
7.17 \\
- \\
\end{array}$ & $\begin{array}{l}5.00 \\
86.00 \\
- \\
\end{array}$ & $2.95 *$ & .003 \\
\hline & $\overbrace{\tilde{b}}^{2} \sim$ & $\begin{array}{l}\text { Negatif sıra } \\
\text { Pozitif sıra } \\
\text { Esit }\end{array}$ & $\begin{array}{l}4 \\
6 \\
17\end{array}$ & $\begin{array}{l}5.50 \\
5.50 \\
-\end{array}$ & $\begin{array}{l}22.00 \\
33.00 \\
-\end{array}$ & $.63 *$ & .527 \\
\hline
\end{tabular}

*Negatif siralar temeline dayalı

Tablo 5: GRUP 1 öğrencilerinin hipotez kurma ön test-son test ortalama puanlarının t-testi sonuçları

\begin{tabular}{ccccccc}
\hline Ölçüm & $\mathrm{N}$ & $\overline{\mathrm{X}}$ & $\mathrm{S}$ & $\mathrm{sd}$ & $\mathrm{T}$ & $\mathrm{p}$ \\
\hline Ön Test & 26 & 4.96 & 1.34 & 25 & -2.23 & .035 \\
Son Test & 26 & 5.61 & 1.16 & & & \\
\hline
\end{tabular}

Uygulama sonrası elde edilen veriler, GRUP 1 öğrencilerinin BSBT'den aldıkları puanların ortalamasının 25.84, GRUP 2 öğrencilerininkinin ise 27.11 olduğunu göstermektedir. Burada GRUP 2 öğrencilerinin BSBT'den aldıkları puanların ortalamasının GRUP 1 öğrencilerininkinden yüksek olduğu görülmektedir. Ancak GRUP 1 öğrencilerinin bilimsel süreç becerileri açısından GRUP 2 öğrencilerine göre daha düşük seviyede oldukları dikkate alındığında; her iki gruptaki öğrencilerin puanlarını ne kadar artırabildiği konusu önemli hale gelmektedir.

Tablo 6: Uygulama sonrası BSBT son testinin gruba göre betimsel analiz sonuçları

\begin{tabular}{cccc}
\hline Grup & $\mathrm{N}$ & $\overline{\mathrm{X}}$ & $\mathrm{SD}$ \\
\hline GRUP 1 & 26 & 25.84 & 3.70 \\
GRUP 2 & 27 & 27.11 & 3.54 \\
\hline
\end{tabular}




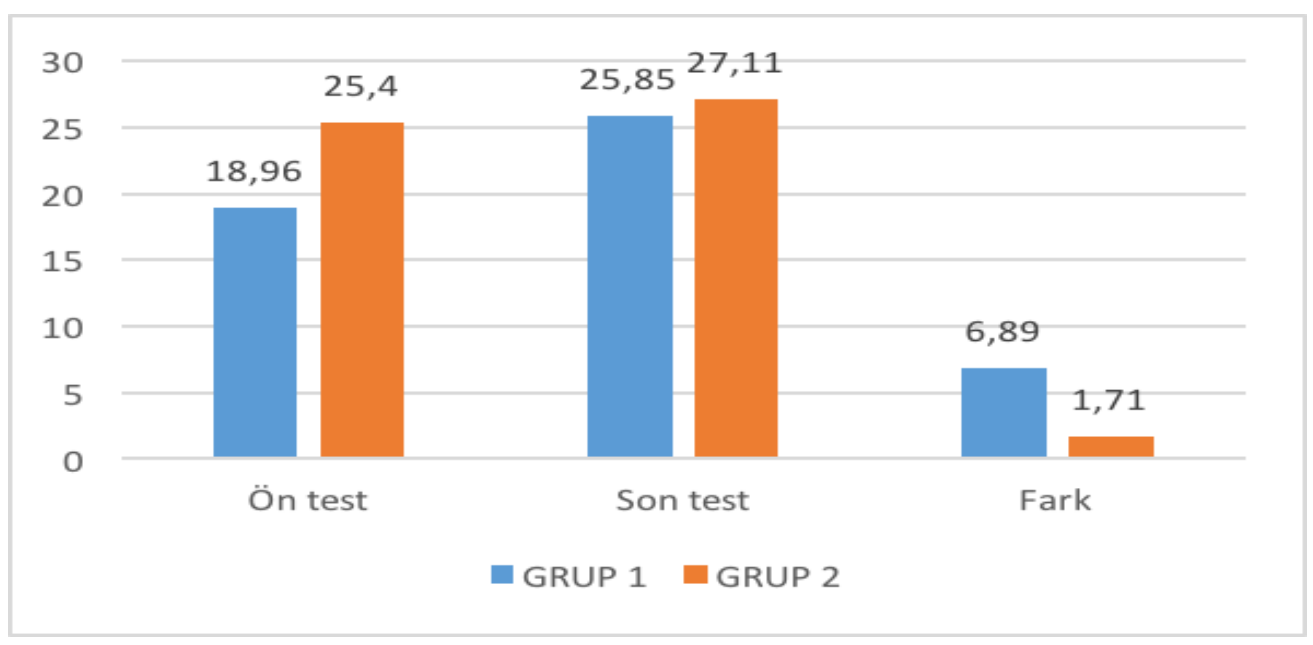

\section{Grafik 3.1. GRUP 1 ve GRUP 2 öğrencilerinin BSBT’ne iliş̧kin puanların ortalamaları}

Grafik 3.1. incelendiğinde; GRUP 1 öğrencilerinin son test ile ön test puanlarının ortalamaları arasındaki farkın 6.89; GRUP 2 öğrencilerininkinin ise 1.71 olduğu görülmektedir. Bu durum; bilimsel süreç becerileri daha düşük olan GRUP 1 öğrencilerinin, bilimsel süreç becerileri daha yüksek olan GRUP 2 öğrencilerine göre BSBT'den aldıkları puanları uygulama sonunda daha fazla artırdıklarını göstermektedir.

Tablo 7: Becerilere ilişkin son test puanlarının gruba betimsel analiz sonuçları

\begin{tabular}{lllll}
\hline Bilimsel Süreç Becerileri & Grup & $\mathrm{N}$ & $\overline{\mathrm{X}}$ & SD \\
\hline Değişkenleri Belirleme & GRUP 1 & 26 & 8.84 & 2.58 \\
& GRUP 2 & 27 & 8.92 & 2.52 \\
\hline Operasyonel Tanımlama & GRUP 1 & 26 & 3.88 & 1.10 \\
& GRUP 2 & 27 & 3.70 & 1.03 \\
\hline Hipotez Kurma & GRUP 1 & 26 & 5.61 & 1.16 \\
& GRUP 2 & 27 & 6.74 & 1.43 \\
\hline Veri ve Grafik Yorumlama & GRUP 1 & 26 & 5.19 & .93 \\
& GRUP 2 & 27 & 5.18 & .83 \\
\hline Araştırma Tasarlama & GRUP 1 & 26 & 2.30 & .67 \\
& GRUP 2 & 27 & 2.55 & .50 \\
\hline
\end{tabular}

Uygulama sonrası elde edilen puanların ortalamaları bilimsel süreç becerilerinin alt boyutları açısından incelendiğinde; her iki gruptaki öğrencilerin değişkenleri belirleme, operasyonel tanımlama, veri ve grafik yorumlama, araştırma tasarlama becerileriyle ilgili puanlarının ortalamalarının birbirine çok yakın olduğu görülmektedir. Yalnızca hipotez kurma becerisiyle ilgili puanların ortalamasının GRUP 2'de GRUP 1'e kıyasla biraz yüksek olduğu anlaşılmaktadır.

$\mathrm{Bu}$ çalışmada incelenen bir başka konu; argümantasyona dayalı laboratuar uygulamalarının öğrencilerin kimya laboratuarı dersine karşı tutumlarına etkisidir. Bu amaçla KLDTÖ puanlarına ilişkin karşılaştırma yapılmıştır. GRUP 1 için tutum son test, GRUP 2 için tutum ön test normal dağılım göstermediği için nonparametrik istatistikler kullanılmıştır.

Tablo 8: Uygulama öncesi KLDTÖ puanlarının gruba göre betimsel analiz sonuçları

\begin{tabular}{cccc}
\hline Grup & N & $\bar{X}$ & SD \\
\hline GRUP 1 & 26 & 125.96 & 27.22 \\
GRUP 2 & 27 & 137.81 & 14.47 \\
\hline
\end{tabular}


Tablo 8'e göre GRUP 1 ve GRUP 2 öğrencilerinin KLDTÖ'nden aldıkları puanların ortalamaları sırasıly 125.96 ve 137.81 'dir. KLDTÖ'den alınabilecek en yüksek puan 175.00'dir. Tablo 8'de verilen sonuçlar; GRUP 2 öğrencilerinin kimya laboratuarı dersine karşı tutumlarının olumlu yönde biraz daha yüksek olduğunu göstermektedir.

Tablo 9: KLDTÖ ön test-son test puanlarına ilişkin Wilcoxon işaretli sıralar testi sonuçları

\begin{tabular}{lllllll}
\hline Grup & Son test-Ön test & $\mathrm{n}$ & Sıra Ort. & Sira Top. & $\mathrm{z}$ & $\mathrm{p}$ \\
\hline GRUP 1 & Negatif sıra & 9 & 10.67 & 96.00 & $2.02 *$ & .043 \\
& Pozitif sıra & 17 & 15.00 & 255.00 & & \\
& Eşit & 0 & - & - & & \\
\hline GRUP 2 & Negatif sıra & 8 & 10.50 & 84.00 & $2.52 *$ & .012 \\
& Pozitif sıra & 19 & 15.47 & 294.00 & & \\
& Eşit & 0 & - & - & & \\
\hline
\end{tabular}

*Negatif sıralar temeline dayalı

GRUP 1 ve GRUP 2 öğrencilerinin uygulama öncesi ve sonrası kimya laboratuarı dersine karşı tutumlarında anlamlı bir farklılık oluşup oluşmadığına ilişkin Wilcoxon İşaretli Sıralar Testi sonuçları Tablo 9'da verilmiştir. Analiz sonuçları, hem GRUP 1 hem de GRUP 2 öğrencilerinin tutum ölçeğinden aldıkları uygulama öncesi ve sonrası puanları arasında anlamlı bir fark olduğunu göstermektedir $(\mathrm{z}=2.02, \mathrm{p}<.05 ; \mathrm{z}=2.52, \mathrm{p}<.05)$. Fark puanlarının sira ortalaması ve toplamları dikkate alındığında, pozitif sıralar yani son test puanı lehine bir farkın olduğu görülmektedir. Bu sonuçlara göre; argümantasyona dayalı laboratuar uygulamalarının öğrencilerin kimya laboratuarı dersine karşı tutumlarının artmasına neden olduğu söylenebilir.

Tablo 10: Uygulama sonrası KLDTÖ puanlarının gruba göre betimsel analiz sonuçları

\begin{tabular}{cccc}
\hline Grup & $\mathrm{N}$ & $\overline{\mathrm{X}}$ & $\mathrm{S}$ \\
\hline GRUP 1 & 26 & 143.07 & 22.28 \\
GRUP 2 & 27 & 146.96 & 14.88 \\
\hline
\end{tabular}

Tablo 10 incelendiğinde; GRUP 1 ve GRUP 2 öğrencilerinin uygulama sonrasinda KLDTÖ'den aldıkları puanların ortalamalarının sırasıyla 143.07 ve 146.96 olduğu görülmektedir. Son test ortalama puanların GRUP 2 açısından yüksek olduğu görülmekle beraber ön teste kıyasla değerlerin birbirine daha yakın olduğu söylenebilir. Yine bu durumda öğrencilerin KLDTÖ puanlarının ortalamasını uygulama öncesi ve sonrası kıyasıyla ne kadar artırdıklarını incelemek, grupları karşılaştırmak açısından daha anlamlı olacaktır.

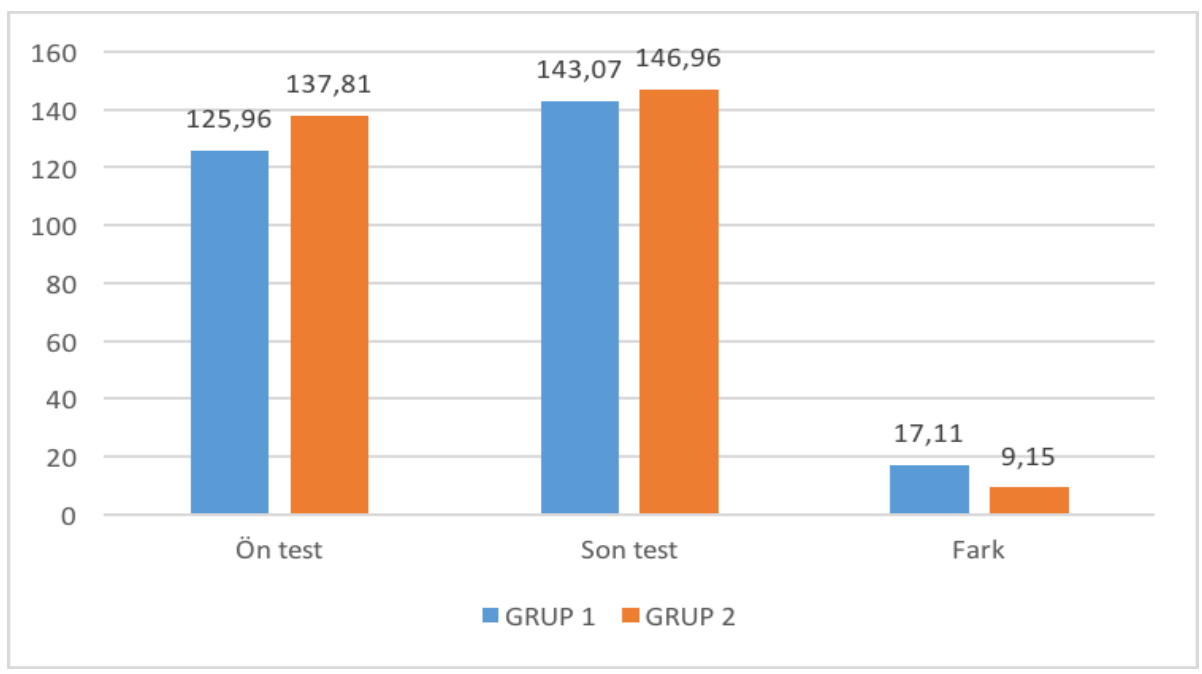

Grafik 3.2. GRUP 1 ve GRUP 2 öğrencilerinin KLDTÖ'ne ilişkin puanların ortalamaları 
Grafik 3.2. incelendiğinde; GRUP 1 öğrencilerinin KLDTÖ son test ile ön test puanlarının ortalamaları arasındaki farkın 17.11; GRUP 2 öğrencilerininkinin ise 9.15 olduğu görülmektedir. $\mathrm{Bu}$ durum; bilimsel süreç becerileri daha düşük olan GRUP 1 öğrencilerinin, bilimsel süreç becerileri daha yüksek olan GRUP 2 öğrencilerine göre KLDTÖ’den aldıkları puanları uygulama sonunda daha fazla artırdıklarını göstermektedir.

\subsection{Nitel Bulgular}

$\mathrm{Bu}$ bölümde öğrencilerin argümantasyona dayalı laboratuar uygulamalarına ilişkin görüşlerine ait bulgular yer almaktadır. Öğrenci görüşlerinin içerik analizi aşağıda sunulmuştur:

Tablo 11: Argümantasyona dayalı laboratuar uygulamalarına ilişkin öğrenci görüşleri

\begin{tabular}{|c|c|c|c|}
\hline Temalar ve Kodlar & Örnek İfadeler & f & $\%$ \\
\hline Faydalı buldum. & & 14 & 73.7 \\
\hline $\begin{array}{l}\text { Akademik başarı } \\
\text { * Pekiştirme } \\
\text { * Derinlemesine anlama } \\
\text { * Kalıcı ögrenme } \\
\text { * Not kaygısı }\end{array}$ & $\begin{array}{l}\text { - "Bu yöntemde bir konu ders içerisinde birkaç kez pekiştiriliyordu. O } \\
\text { yüzden güzel. Deney hakkında bilgi sahibi olarak dersten } \\
\text { çıkıyordum." } \\
\text { - "Grup içerisinde tartışarak beyin firtınası yapmamız çok güzeldi. } \\
\text { Daha iyi anlamamızı sağladı." } \\
\text { - "Deneyden önce ve deney sırasında geçmiş bilgilerimizi } \\
\text { kullanmamız, deney yaptıktan sonra nerede hata yaptığımızı } \\
\text { görmemizi sağladı. Farklı düşünmemize sebep oldu. Bu durum } \\
\text { bilgilerin daha kalıcı olmasını sağladı." } \\
\text { - "Not kaygısının olmaması gerilmememizi sağladı. Bireysel ve grup } \\
\text { formları ile yaptığımız uygulamalar ile bilgiye kendimiz ulaştık. Çok } \\
\text { faydalı oldu." } \\
\text { - "Hocamızla deney ile ilgili tartışmak, aklımızda daha iyi kalmasını } \\
\text { sağladı. Daha iyi öğrendiğimi düşünüyorum." }\end{array}$ & 7 & $\% 33.3$ \\
\hline $\begin{array}{l}\text { Kişisel Gelişim } \\
\text { * Düşünme becerisini } \\
\text { geliştirme } \\
* \quad \text { Başkalarının fikirlerini } \\
\text { önemseme } \\
\text { * Sorgulamayı/soru sormayı } \\
\text { ögrenme } \\
\text { * Farklı bakış açıları } \\
\text { geliştirme } \\
\text { * Kendini ifade edebilme }\end{array}$ & $\begin{array}{l}\text { - "Önceden deneyden önce ve sonra ne düşündüğümün önemi yoktu. } \\
\text { Düşüncelerimin farkına vardım." } \\
\text { - "Düşünme becerilerimin geliştiğini düşünüyorum." } \\
\text { - "Daha önceden deneyden ne beklediğimin ya da grup arkadaşlarımla } \\
\text { aynı fikirde olup olmamam önemli değildi. Bunun önemini } \\
\text { farkettim." } \\
\text { - "Hocamızla deney konusunda tartışarak, deneyle ilgili fikirlerimi } \\
\text { söylemem kendimi daha rahat ifade etmem açısından faydalı oldu." } \\
\text { - "Bu uygulama gelecekte öğretmenlik hayatımda daha rahat ve } \\
\text { mantıklı sorular sormama yardımcı olacak." } \\
\text { - "Bu uygulamanı bilgilerimi ve görüşlerimi genişlettiğini } \\
\text { düşünüyorum. Bu sayede konulara farklı açılardan bakabildik ve } \\
\text { tartışma ile farklı fikirler ortaya çıktı." }\end{array}$ & 14 & $\% 66.7$ \\
\hline Faydalı bulmadım. & & 5 & 26.3 \\
\hline $\begin{array}{l}\text { Akademik Başarı } \\
* \text { Kalıcı öğrenme } \\
* \text { Not kaygısı }\end{array}$ & $\begin{array}{l}\text { - "Arkadaşlardan fikir edinmeye çalışmak, not kaygısının olmaması } \\
\text { yüzünden faydalı bulmadım. Diğer laboratuar derslerinde yaptığımız } \\
\text { gibi quiz yapıp deneyi yapmak, sonucu bulup rapor yazmak daha iyi." } \\
\text { - "Quiz sisteminin olmaması not kaygısının da olmamasına neden oldu. } \\
\text { Not kaygısı olunca daha iyi hazırlık yapıyorum. O zaman daha kalıcı } \\
\text { oluyor." }\end{array}$ & 5 & 26.3 \\
\hline
\end{tabular}

Tablo 11 incelendiğinde; görüşleri alınan öğrencilerin \%73.7'sinin argümantasyona dayalı laboratuar uygulamalarını faydalı bulduğu görülmektedir. Öğrenciler bu faydaları; akademik başarı ve kişisel gelişim üzerindeki olumlu etkileri şeklinde değerlendirmişlerdir. Uygulamayı faydalı bulmayan öğrencilerin tamamı ise; bu düşüncelerinin nedeni olarak uygulamaların akademik başarıya olan olumsuz etkilerini göstermişlerdir. 


\section{TARTIŞMA, SONUÇ VE ÖNERİLER}

$\mathrm{Bu}$ araştırma; bilimsel süreç becerileri açısından daha düşük ve daha yüksek düzeyde olmak üzere iki grupla yürütülmüştür. Burada temel amaç; argümantasyona dayalı laboratuar uygulamalarının öğrencilerin bilimsel süreç becerilerine ve derse yönelik tutumlarına olan etkisini ve bu etkinin bilimsel süreç becerileri daha az ve daha fazla gelişmiş öğrenciler üzerinde nasıl gerçekleştiğini belirlemektir. Bu amaçla öncelikle öğrencilerin BSBT'den aldıkları puanlar incelenmiştir. İnceleme sonucunda elde edilen bulgular BSBT toplam puanları üzerinden değerlendirildiğinde; argümantasyona dayalı laboratuar uygulamalarının her iki gruptaki öğrencilerin de bilimsel süreç becerilerini geliştirdiği görülmüştür. Becerilerin alt boyutları açısından değerlendirme yapıldığında ise; her iki gruptaki öğrencilerinde alt boyutlara ilişkin becerilerin her birinde puanlarını artırdıkları görülmüştür. Ancak GRUP 1 öğrencilerinin her bir beceriye ait puanlarını GRUP 2 öğrencilerine göre daha fazla artırdıkları dikkat çekmiştir. Grupların BSBT'den aldıkları son test toplam puanları karşılaştırıldığında, GRUP 1 ve GRUP 2 öğrencileri aldıkları son test toplam puanların ortalamalarının birbirine çok yakın olduğu ( $\mathrm{X}_{\mathrm{GRUP}}$ $\left.{ }_{2}=27.11 ; \mathrm{X}_{\mathrm{GRUP}}{ }_{1}=25.85\right)$, BSBT son test ve ön test puan ortalamalarının fark1 karşılaştırıldığında ise GRUP 1 öğrencilerinin fark puanlarının GRUP 2 öğrencilerininkinden daha yüksek olduğu görülmüştür $\left(\mathrm{X}_{\mathrm{GRUP} 2}=1.71 ; \mathrm{X}_{\mathrm{GRUP} 1}=6.89\right)$. Çalışmadan elde edilen tüm bu bulgular, argümantasyona dayalı laboratuar uygulamalarının öğrencilerin bilimsel süreç becerilerini geliştirdiğini göstermektedir. $\mathrm{Bu}$ sonuç, literatürde yer alan argümantasyonun bilimsel süreç becerilerini geliştirdiği yönündeki çalışmaları destekler niteliktedir (Aslan, 2010; Cin, 2013; Çoban, 2013; Gültepe, 2011). Ayrıca öğrenci merkezli uygulamalar ile bilimsel süreç becerilerinin geliştirilebileceğine yönelik çalışmalarla da uyum göstermektedir (Kanlı ve Yağbasan, 2008; Karamustafaoğlu, 2011; Osman ve Vebrianto, 2013; Özer ve Özkan, 2012). Bu araştırmanın dikkat çeken noktası; argümantasyona dayalı laboratuar uygulamalarının bilimsel süreç becerileri zayıf olan öğrenciler üzerindeki etkisinin, bilimsel süreç becerileri daha fazla gelişmiş olan öğrencilere göre daha fazla olmasıdır. Bu bulgu; argümantasyonun bilişsel açıdan daha düşük seviyeli öğrencilerle yürütülmesindeki kaygıyı ve bu öğrencilere katkı sağlamada etkili olamayacağı yönündeki inancı çürütecek nitelik taşımaktadır.

Araştırmada ele alınan bir başka konu; argümantasyona dayalı laboratuar uygulamalarının öğrencilerin derse karşı tutumlarına olan etkisini belirlemektir. Buna ilişkin araştırma bulguları; uygulamaların öğrencilerin derse karşı tutumlarını olumlu yönde artırdığı şeklindedir. Bu sonuç, argümantasyon kullanımının derse yönelik tutumu olumlu yönde artırdığını ifade eden çalışmaları da destekler niteliktedir (Günel, Kabataş-Memiş ve Büyükkasap, 2010; Keys ve diğerleri, 1999; Köseoğlu, Tümay ve Akben, 2007; Walker ve diğerleri, 2012). Bu çalışmada dikkat çeken nokta; argümantasyona dayalı laboratuar uygulamalarının bilimsel süreç becerileri zayıf olan öğrencilerin (GRUP 1) derse karşı tutumlarını, bilimsel süreç becerileri daha fazla gelişmiş olan öğrencilere (GRUP 2) kıyasla olumlu yönde daha fazla artırmış olmasıdır (KLDTÖ ön test-son test puan ortalamalar1 fark1: $\mathrm{X}_{\mathrm{GRUP} 2}=9.15 ; \mathrm{X}_{\mathrm{GRUP}} 1=17.11$ ). $\mathrm{Bu}$ durum GRUP 1 öğrencilerinin -laboratuar dersi aracıllı̆ı̆yla geliştirilmesi hedeflenen- bilimsel süreç becerilerinin, GRUP 2 öğrencilerine kıyasla uygulama sonunda daha fazla gelişme göstermesine neden olan etkenlerden biri olarak düşünülebilir. Başka bir ifadeyle; derse karşı tutumu olumlu yönde daha fazla artan öğrencilerin, bilimsel süreç becerilerini de daha fazla geliştirebildikleri söylenebilir. Derse karşı olumlu tutumun öğrenme ortamlarında kolaylık ve başarı sağladığı düşünüldüğünde; laboratuar dersine karşı tutumun olumlu yönde artmasının bilimsel süreç becerilerinin geliştirilmesine katkı sağladığı ifade edilebilir. Çalışmaya katılan öğrencilerde derse karşı tutumun olumlu yönde artmasında ise uygulama sürecinin etkili olduğu düşünülmektedir. $\mathrm{Bu}$ nedenle argümantasyona dayalı laboratuar uygulamalarının öğrencilerin derse karşı tutumlarına olan etkisini daha iyi irdeleyebilmek için öğrenci görüşlerine de başvurulmuştur. 19 öğrencinin uygulamaya ilişkin görüşleri alındığında; öğrencilerden 14'ünün 
uygulamayı faydalı bulduğu, 5'inin ise faydalı bulmadığı görülmüştür. Faydalı bulmayan öğrencilerin 4'ü GRUP 2, 1'i ise GRUP 1 öğrencisidir. Bu durum grupların uygulama öncesi ve sonrasında laboratuar dersine yönelik tutumlarına ilişkin bulgularla birlikte değerlendirildiğinde; derse yönelik tutumun olumlu yönde artmasında yapılan uygulamanın etkili olduğunu daha güçlü bir biçimde düşündürmektedir. Uygulamayı faydalı bulan öğrencilerin belirttikleri iki nokta göze çarpmaktadır. Bu noktalardan birincisi, uygulamaların kişisel gelişime olan katkısıdır. Argümantasyonun olası faydaları arasında sıralanan bu durumlar (Manoley ve Simon, 2006; Erduran, Simon ve Osborne, 2004; Kuhn, aktaran, Park, 2006), öğrenciler tarafindan da ifade edilmiştir. $\mathrm{Bu}$ bağlamda öğrenciler uygulamaların, düşünme becerilerini, başkalarının fikirlerini önemsemeyi, sorgulamayı ve soru sormayı, farklı bakış açıları geliştirmeyi ve kendini daha rahat ifade edebilmeyi desteklediğini belirtmişlerdir. Fen eğitimi ile fen okuryazarı bireyler yetiştirme hedefi (American Association for the Advancement of Science [AAAS], 1989; TTKB, 2005, 2013) ve 21. yüzy1l bireylerinin sahip olmas1 gereken beceriler (Partnership for 21st Century Learning, 2015) birlikte düşünüldüğünde, argümantasyona dayalı laboratuar uygulamalarına ilişkin öğrencilerin ifade ettikleri bu faydalar, önem taşımaktadır. Uygulamaları faydalı bulan öğrencilerin belirttikleri ikinci nokta; uygulamaların akademik başarıya olan etkisidir. Aslında bu durum uygulamaları faydalı bulmayan öğrencilerin neden faydalı bulmadıklarına ilişkin gerekçelerini oluşturmaktadır. Burada tezat iki durum ortaya çıkmaktadır. Uygulamayı faydalı bulan öğrenciler, uygulama ile derinlemesine anladıklarını, pekiştirmenin olduğunu, öğrenmenin daha kalıcı olduğunu, not kaygısı yaşamadıklarını ve bu durumun kendilerini olumlu etkilediğini ifade ederken, faydalı bulmayan öğrenciler not kaygısı olmamasının kendilerini olumsuz etkilediğini, not kaygısı olmadığında daha iyi hazırlanamadıklarını ve bu yüzden kalıcı öğrenmenin gerçekleşmediğini ifade etmişlerdir. Bu görüşler; geleneksel şekilde yürütülen laboratuar uygulamalarının (quiz-deney prosedürünün uygulanmas1-sonuçların elde edilmesi-deney raporunun yazılması) geleneksel şekilde yürütülen derslere benzediği ve bu şekilde yürütülen derslere öğrencilerin alışmış olma ihtimalinin, yeni uygulamaların öğrenciler tarafindan benimsenmesini zorlaştırdığını düşündürmektedir. Öğrencilerin tutum testinden aldıkları puanların karşılaştırılmasından elde edilen sonuçlar bu görüşlerle birlikte değerlendirildiğinde; her ne kadar argümantasyona dayalı laboratuar uygulamalarına ilişkin görüşleri alınan öğrencilerin \%73.7's1 uygulamaları faydalı bulsa da, \%26.3'ünün faydalı bulmadığı görülmektedir. Araştırmaya ilişkin nicel veriler, argümantasyona dayalı laboratuar uygulamalarının öğrenciler tarafindan benimseneceği ve uygulamanın yürütülmesine ilişkin olumlu tutumlar geliştireceklerini düşündürse de, bazı öğrenciler için bu düşüncenin geçerli olmadığı görülmektedir. Öğrencilerin büyük çoğunluğunun daha önceki öğrenim hayatlarında geleneksel yöntemlerle derslerin yürütüldüğü bir süreçten geçtikleri varsayılır ve bu yöntemlere alışmış olan öğrencilerin on haftalık süreçte büyük olasılıkla aşina olmadıkları bir uygulamayla karşılaştıkları dikkate alınırsa, neden bazı öğrencilerin uygulamaya ilişkin olumsuz düşüncelere sahip olduğu daha anlaşılabilir hale gelebilir. $\mathrm{Bu}$ durum öğrencilerdeki bariyeri göstermekte ve daha ileri seviyelerde öğrenim gören öğrencilerin dirençlerinin de daha fazla olabileceğini düşündürmektedir. $\mathrm{Bu}$ nedenle; yenilikçi öğretim uygulamalarının alt sınıflardan itibaren kullanılması ve bu uygulamalar aracığıyla bilgi ve becerilerin kazandırılması önem taşımaktadır.

$\mathrm{Bu}$ araştırmanın sonuçları; lisans düzeyindeki öğrencilerin bilimsel süreç becerilerinin geliştirilmesi ve laboratuar dersine karşı tutumlarının olumlu yönde artırılması için argümantasyona dayalı laboratuvar uygulamalarının kullanılabileceğini göstermektedir. $\mathrm{Bu}$ nedenle laboratuar derslerinin tasarımı, argümantasyonu uygulamaya firsat sunacak şekilde yapılabilir. Ayrıca öğrencilerin etkin bir şekilde argümantasyon uygulamalarına katılabilmeleri ve lisans düzeyindeki bilimsel bilginin yapılandırılmasında argümantasyonu kullanabilmeleri için; alt sınıflardan itibaren argümantasyon deneyimi yaşayacakları firsatlar sunulabilir. Ögretmen adaylarının feni öğretirken argümantasyonu nasıl kullanabileceklerine ilişkin 
etkinlikler, fenin nasıl öğretileceğini konu alan derslerde incelenebilir. Böylece yeni Fen Bilimleri Öğretim Programı'nın da öngördüğü 'argümantasyonun kullanıldığ̀ fen öğretimi' amacına katk1 sağlanabilir.

\section{KAYNAKLAR}

Acar, B. Ş., \& Tarhan, L. (2013). Inquiry-based laboratory activities in electrochemistry: High school students' achievements and attitudes. Research in Science Education, 43(1), 413-435.

Açışl1, S. ve Turgut, Ü. (2011). Fizik laboratuar uygulamalarında 5E öğrenme modeline uygun olarak geliştirilen materyallerin öğrenci kazanımlarına etkisinin incelenmesi. International Online Journal of Educational Sciences, $3(2), 562-593$.

Alkan, F. ve Erdem, E. (2013). Kendi kendine öğrenmenin laboratuarda başarı, hazırbulunuşluk, laboratuar becerileri tutumu ve endişeye etkisi. Hacettepe Üniversitesi Eğitim Fakültesi Dergisi, 44, 15-26.

American Association for the Advancement of Science, [AAAS], (1989). Science for all Americans. [Available online at: http://project2061.aaas.org/tools/sfaaol/sfaatoc.htm], Erişim tarihi: 15 Kasım 2013.

Aslan, S. (2010). Ortaöğretim 10. sınıf ögrrencilerinin üst bilimsel süreç ve eleştirel düsünme becerilerinin geliştirilmesine bilimsel tartışma odaklı öğretim yaklaşımının etkisi. Yayımlanmamış Doktora Tezi. Gazi Üniversitesi, Eğitim Bilimleri Enstitüsü, Ankara.

Ateş, S. ve Bahar, M. (2002). Araştırmacı fen öğretimi yaklaşımıyla sınıf öğretmenliği 3.sınıf öğrencilerinin bilimsel yöntem yeteneklerinin geliştirilmesi. V. Ulusal Fen Bilimleri ve Matematik Eğitimi Kongresi, Orta Doğu Teknik Üniversitesi, Ankara.

Aydın, S. (2011). Effect of cooperative learning and traditional methods on students' achievements and identifications of laboratory equipments in science-technology laboratory course. Educational Research and Reviews, 6(9), 636644.

Bilen, K. ve Aydoğdu, M. (2012). Tahmin et-gözle-açıkla (TGA) stratejisine dayalı laboratuar uygulamalarının öğrencilerin bilimsel süreç becerileri ve bilimin doğası hakkındaki düşünceleri üzerine etkisi. Gaziantep Universitesi Sosyal Bilimler Dergisi (http://sbe.gantep.edu.tr),11(1), 49 -69, ISSN: 1303-0094.

Burke, K., Hand, B., Poock, J., \& Greenbowe, T. (2005). Using the science writing heuristic: Training chemistry teaching assistants. Journal of College Science Teaching, 35(1), 36-41.

Burns, J. C., Okey, J. C., \& Wise, K. (1985). Development of an integrated process skills test: TIPS II. Journal of Research in Science Teaching, 22(2), 169-177.

Cin, M. (2013). Argümantasyon yöntemine dayalı kavram karikatürü etkinliklerinin ögrrencilerin kavramsal anlama düzeylerine ve bilimsel süreç becerilerine etkileri. Yayımlanmamış Yüksek Lisans Tezi. Dokuz Eylül Üniversitesi, Eğitim Bilimleri Enstitüsü, İzmir.

Çoban, G. Ü. (2013). The effects of inquiry supported by argument maps on science process skills and epistemological views of prospective science teachers. Journal of Baltic Science Education, 12(3), 271-288.

Doymuş, K., Şimşek, Ü. ve Karaçöp, A. (2007). Genel kimya laboratuarı dersinde öğrencilerin akademik başarısına, laboratuar malzemelerini tanıma ve kullanmasına işbirlikli ve geleneksel öğrenme yönteminin etkisi. Eurasian Journal of Educational Research, 28, 31-43.

Erduran, S., Simon, S., \& Osborne, J. (2004). TAPping into argumentation: Developments in the application of Toulmin's Argument Pattern for studying science discourse. Science Education, 88(6), 915-933.

Geban, Ö., Aşkar, P., \& Özkan, İ. (1992). Effects of computer simulations and problem-solving approaches on high school students. Journal of Educational Research, 86(1), 5-10.

Gültepe, N. (2011). Bilimsel tartışma odaklı öğretimin lise ögrrencilerinin bilimsel süreç ve eleştirel düşünme becerilerinin geliştirilmesine etkisi. Yayımlanmamış Doktora Tezi. Gazi Üniversitesi, Eğitim Bilimleri Enstitüsü, Ankara.

Günel, M., Kabataş-Memiş, E. ve Büyükkasap, E. (2010). Yaparak yazarak bilim öğrenimi-YYBÖ yaklaşımının ilköğretim öğrencilerinin fen akademik başarısına ve fen dersine yönelik tutumuna etkisi. Eğitim ve Bilim, 35 (155), 49-62.

Günel, M., Kıngır, S. ve Geban, Ö. (2012). Argümantasyon tabanlı bilim öğrenme (ATBÖ) yaklaşımının kullanıldığı sınıflarda argümantasyon ve soru yapılarının incelenmesi. Eğitim ve Bilim, 37(164), 316-330. 
Kanlı, U. (2007). 7E Modeli merkezli laboratuar yaklaşımı ile doğrulama laboratuar yaklaşımlarının öğrencilerin bilimsel süreç becerilerinin gelişimine ve kavramsal başarılarına etkisi. Yayımlanmamış Doktora Tezi. Gazi Üniversitesi, Eğitim Bilimleri Enstitüsü, Ankara.

Kanl1, U., \& Temiz, B. K. (2006). The sufficiency of the numerical questions in the OSS examination in the year 2003 on the measurement of the students' scientific process skills. Eğitim ve Bilim, 31(140), 62-67.

Kanlı, U. ve Yağbasan, R. (2008). 7E Modeli merkezli laboratuar yaklaşımının öğrencilerin bilimsel süreç becerilerini geliştirmedeki yeterliliği. GÜ, Gazi Eğitim Fakültesi Dergisi, 28(1), 91-125.

Karamustafaoğlu, S. (2011). Improving the science process skills ability of science student teachers using I diagrams. Eurasian Journal of Physics \& Chemistry Education, 3(1), 26-38.

Kaya, D. B. (2012). Temel kimya laboratuar dersinin web ortamı ile desteklenmesinin öğrencilerin başarısına ve derse yönelik tutumuna etkisi. Yayımlanmamıș Doktora Tezi. Dicle Üniversitesi, Fen Bilimleri Enstitüsü, Diyarbakır.

Keys, C. W., Hand, B., Prain, V., \& Collins, S. (1999). Using the science writing heuristic as a tool for learning from laboratory investigations in secondary science. Journal of Research in Science Teaching, 36(10), 1065-1084.

Köseoğlu, F., Tümay, H. ve Akben, N. (2007). Argümantasyona dayalı öğretim uygulamaların ögrencilerin asitlik/bazlık kuvveti, derişim ve pH konusundaki kavramsal değişimlerine ve kimyaya karşı tutumlarına etkisi. I. Ulusal Kimya Eğitimi Kongresi, İstanbul.

Manoley, J., \& Simon, S. (2006). Mapping children's discussion of evidence in science to assess collaboration and argumentation. International Journal of Science Education, 28(15), 1817-1841.

Miles, M. B., \& Huberman, A. M. (1994). Qualitative data analysis: An expanded source book (2nd ed.). California: SAGE Publications.

Nam, J., Choi, A., \& Hand, B. (2011). Implementation of the science writing heuristic (SWH) approach in 8th grade science classrooms. International Journal of Science and Mathematics Education, 9(5), 1111-1133.

Osman, K., \& Vebrianto, R. (2013). Fostering science process skills and improving achievement through the use of multiple media. Journal of Baltic Science Education, 12(2), 191-204.

Özer, D. Z. ve Özkan, M. (2012). Proje tabanlı öğretimin fen bilgisi öğretmen adaylarının bilimsel süreç becerilerine etkisi. Türk Fen Ĕ̈itimi Dergisi(TÜFED), 9(3), 119-130.

Özmen, H., Demircioğlu, G., Burhan, Y., Naseriazar, A., \& Demircioğlu, H. (2012). Using laboratory activities enhanced with concept cartoons to support progression in students' understanding of acid-base concepts. AsiaPacific Forum on Science Learning and Teaching, 13(1), Article 8.

Park, Y. S. (2006). Analyzing explicit teaching strategies and student discourse for scientific argumentation. Unpuplished Doctoral Dissertation. Oregon State University, USA.

Partnership for 21st Century Learning. (2015). P21 Framework definitions. [Available online at: http://www.p21.org/ storage/documents/docs/P21_Framework_Definitions_New_Logo_2015.pdf], Erişim tarihi: 28 Ocak 2014.

Talim Terbiye Kurulu Başkanlı̆̆ı, [TTKB], (2005). İlköğretim Fen ve Teknoloji Dersi 4. ve 5. Sinıflar Öğretim Programı Kılavuzu. [Çevrim-içi: http://ttkb.meb.gov.tr/www/ogretim-programlari/icerik/72], Erişim tarihi: 17 Ocak 2013.

Talim Terbiye Kurulu Başkanlı̆̆ı, [TTKB], (2006). İlköğretim Fen ve Teknoloji Dersi 6., 7. ve 8. Sinıflar Öğretim Programı. [Çevrim-içi: http://ttkb.meb.gov.tr/www/ogretim-programlari/icerik/72], Erişim tarihi: 17 Ocak 2013.

Talim Terbiye Kurulu Başkanlığı, [TTKB], (2013). Fen Bilimleri Dersi (3, 4, 5, 6, 7 ve 8. Sınıflar) Öğretim Programı. [Çevrim-içi: http://ttkb.meb.gov.tr/www/ogretim-programlari/icerik/72], Erişim tarihi: 24 Şubat 2014.

Temel, S. ve Morgil, İ. (2007). Kimya eğitiminde laboratuarda problem çözme uygulamasının öğrencilerin bilimsel süreç becerilerine ve mantıksal düşünme yeteneklerine etkisi. DÜ Buca Eğitim Fakültesi Dergisi, 22, 89-97.

Tüysüz, C. (2010). The effect of the virtual laboratory on students' achievement and attitude in chemistry. International Online Journal of Educational Sciences, 2(1), 37-53.

Walker, J. P., \& Sampson, V. (2013). Learning to argue and arguing to learn: Argument-driven inquiry as a way to help undergraduate chemistry students learn how to construct arguments and engage in argumentation during a laboratory course. Journal of Research in Science Teaching, 50(5), 561-596.

Walker, J. P.,Sampson, V., \& Zimmerman, C. O. (2011). Argument-driven inquiry: An introduction to a new instructional model for use in undergraduate chemistry labs. Journal of Chemical Education, 88(8), 1048-1056. 
Walker, J. P., Sampson, V., Grooms, J., Anderson, B., \& Zimmerman, C. O. (2012). Argument-driven inquiry in undergraduate chemistry labs: The impact on students' conceptual understanding argument skills, and attitudes toward science. Journal of College Science Teaching, 41(4), 74-81.

\section{Extended Abstract}

Recently, there's an increasing emphasis on the use of innovative applications and student-centered laboratory activities in science teaching. The most striking models on the subject are argument-driven inquiry and science writing heuristic. In this study, laboratory activities based on argumentation were designed based on the aforementioned models. In this design, application environment, lecture period, student level and readiness were considered. The steps of the argumentation based laboratory design are provided below;

\begin{tabular}{ll}
\hline & \multicolumn{1}{c}{ Argumentation Based Laboratory } \\
\hline $\begin{array}{l}\text { Introduction } \\
\text { to Laboratory }\end{array}$ & $\begin{array}{l}\text { 1. Finding out the previous learnings of the students about the subject. } \\
\text { 2. Creating and writing down start-up questions (Individual study-group discussion). }\end{array}$ \\
\hline $\begin{array}{l}\text { Experimental } \\
\text { study }\end{array}$ & $\begin{array}{l}\text { 3. Labour division between group members. } \\
\text { 4. Defining and noting the expectations about the experiment. (What do I expect?) (Individual } \\
\text { study-group discussion) } \\
\text { 5. Application of the experimental procedure (procedure is supplied). (Group study) } \\
\text { 6. Recording observations. (My Observations) (Individual study) }\end{array}$ \\
\hline $\begin{array}{l}\text { Data } \\
\text { evaluation }\end{array}$ & $\begin{array}{l}\text { 7. Comparing the expectations and the observations about the experiment and noting. (What do I } \\
\text { expect?) (Individual study-group discussion) }\end{array}$ \\
$\begin{array}{l}\text { Creating } \\
\text { claims }\end{array}$ & $\begin{array}{l}\text { 8. Data evaluation by defining the experiment variables and the relation between variables and } \\
\text { noting them down. (Group discussion) }\end{array}$ \\
justifications & $\begin{array}{l}\text { 9. Creating and noting down claims based on the data (Individual study-group discussion) } \\
\text { (Individual study-group discussion). }\end{array}$ \\
\hline $\begin{array}{l}\text { Self- } \\
\text { evaluation }\end{array}$ & $\begin{array}{l}\text { 11. Comparing the start-up ideas and reached ideas and noting them down. How did my ideas } \\
\text { changed? (Individual study). }\end{array}$ \\
\hline $\begin{array}{l}\text { Group-expert } \\
\text { evaluations }\end{array}$ & $\begin{array}{l}\text { 12. Evaluation of the change in student ideas with group-expert discussion. } \\
\end{array}$
\end{tabular}

This study investigated the effect of argumentation based laboratory activities on students' science process skills and attitudes towards laboratory courses. The study which was designed on mixed methods design was conducted with 53 science pre-teachers studying in a state university in 2012-2013 academic year and taking General Chemistry Laboratory-II. Before the study, Science Process Skills Test (SPST) was applied as a pre-test to the students as a data collection tool, and the students were lined up according to the total score they got from the test. 26 students taking lower scores from the test were grouped as GROUP 1, and 27 students taking higher scores from the test were grouped as GROUP 2. Therefore, the study was started with different two groups in terms of science process skills. This way, it was aimed to compare the effect of argumentation based laboratory applications on students with lower and higher science process skills. During the study, General Chemistry Laboratory-II course was conducted based on argumentation for both groups for ten weeks.

SPST, Chemistry Laboratory Behaviour Scale (CLBS), and written interview form were used to measure the effect of argumentation based laboratory activities on students' science process skills, attitudes towards chemistry laboratory course, and their views about the application, respectively. The opinions of 19 students were acquired this way. When the findings of the study were evaluated with total SPST scores, it was seen that the argumentation based laboratory activities improved science process skills of the students in both groups. An evaluation in terms of sub-dimensions of the skills revealed that the students in GROUP 1 had statistically significant improvement in all sub-dimensions while the students in GROUP 2 had higher but statistically insignificant scores in all sub-dimensions. When SPST post-test total mean scores of the groups were compared, it was found that they were close to each other. However, mean difference between SPST pre-test and post-test scores of the students in GROUP 1 was higher than the students in GROUP 2 had. Therefore, it can be said that the students in GROUP 1 increased their 
SPST scores much more than the students in GROUP 2 did after the argumentation based laboratory activities implementation. When the students' post-test total scores on sub-levels of science process skills were compared, it was seen that the students in each of the groups increased their post-test scores on subdimensions of SPST. However, this rice is much more in students' scores in GROUP 1. The remarkable point in these results is that the effect of the argumentation based laboratory activities on the students with low science process skills is higher that their effect on the students with more improved skills. This finding may refute the worry about conduction argumentation with students who have low cognitive levels and the belief that it may not contribute to these students. The analysis of CLBS scores showed that the application provided a positive increase for both groups of students in their attitudes towards chemistry laboratory course. It was noteworthy to find out that the difference between CLBS pre-test and post-test scores of the students in GROUP 1 was higher than the students' scores in GROUP 2 after the implementation.

When students' views on argumentation based laboratory activities were studied, it was seen that most of the students found the application useful. There are two striking points in these views. The first one is the contribution of the activities to personal development. In this respect, the students stated that the activities support thinking skills, caring for others' ideas, asking questions and questioning, developing different viewpoints, and expressing oneself easily. The second point is the effect of the activities on academic success. The students stated that thanks to the activity, they understand subjects thoroughly, it reinforces learning, their learning is more permanent, they have no concerns about grades, and this affects them positively. The results of this study show that argumentation based laboratory activities can be used to develop under-graduate level students' science process skills and to positively increase students' attitudes towards laboratory courses. 